\title{
Interactions between Chicken Salt-soluble Meat Proteins and Makgeolli Lees Fiber in Heat-induced Gels
}

\author{
Yun-Sang Choi, Kwoan-Sik Park', Hack-Youn Kim¹, Hyun-Wook Kim¹, Dong-Heon Song', \\ Hai-Jung Chung ${ }^{2}$, Ju-Woon Lee ${ }^{3}$, and Cheon-Jei Kim ${ }^{1 *}$ \\ Food and Biological Resources Examination Division, Korean Intellectual Property Office, Daejeon 302-701, Korea \\ ${ }^{1}$ Department of Food Science and Biotechnology of Animal Resources, Konkuk University, Seoul 143-701, Korea \\ ${ }^{2}$ Department of Food Science and Nutrition, Daejin University, Pochon 487-711, Korea \\ ${ }^{3}$ Radiation Technology Institute, Korea Atomic Energy Research Institute, Jeongeup 580-185, Korea
}

\begin{abstract}
The technological effects of Makgeolli lees fiber $(0,0.5,1.0,2.0$, and 4.0\%) on chicken salt-soluble breast meat proteins in a model system on proximate composition, physicochemical properties, and textural properties were investigated. Makgeolli lees fiber was obtained from Makgeolli brew processing, and the by-products showed good dietary fiber. The moisture and ash contents, water holding capacity, redness, yellowness, hardness, and apparent viscosity of chicken salt-soluble meat protein heat-induced gel systems with Makgeolli lees fiber were all higher than the control without Makgeolli lees fiber. However, protein solubility and electrophoretic patterns did not differ among the control and treatments with Makgeolli lees fiber samples. The chicken salt-soluble protein heat-induced gel systems incorporating Makgeolli lees fiber had improved water holding capacity, textural properties, and viscosity due to Makgeolli lees fiber addition. These results suggest that the addition of $4.0 \%$ Makgeolli lees fiber to gel is helpful to improve the physical properties of heat-induced gels.
\end{abstract}

Key words: heat-induced gel, Makgeolli lees fiber, model system, salt-soluble meat protein

\section{Introduction}

The gel formation property implies partial denaturation of protein followed by irreversible aggregation, which results in a three-dimensional network (Choi et al., 2011; Lanier et al., 2004). The heat-induced gelling properties of chicken salt-soluble muscle proteins are the most important functional properties in processed meat products (Smith et al., 1998). The meat proteins remain soluble until heated to $60-70^{\circ} \mathrm{C}$, when heat-set protein gelation occurs (Choi et al., 2011). The gelation of saltsoluble proteins during the heating process is primarily responsible for water and fat stabilization (McCord et al., 1998). In general, muscle proteins can be separated to three groups based on solubility: sarcoplasmatic (watersoluble), myofibrillar (salt-soluble), and stromal (insoluble) proteins (Xiong, 1997). The total muscle protein is composed of approximately $60 \%$ salt-soluble myofibrillar

*Corresponding author: Cheon-Jei Kim, Department of Food Science and Biotechnology of Animal Resources, Konkuk University, Seoul 143-701, Korea. Tel: 82-2-450-3684, Fax: 82-2-444-6695, E-mail: kimcj@konkuk.ac.kr proteins (Koohmaraie et al., 1984). The addition of saltsoluble myofibrillar proteins results in gel formation (Choi et al., 2011; Wang et al., 1990) and are most important during meat processing due to their ability to produce three-dimensional gels upon heating (Verbeken et al., 2005). Choi et al. (2011) investigated the effect of rice bran fiber on the gelation of mixed pork salt-soluble myofibrillar proteins and reported that mixed protein samples displayed improved gel characteristics after rice bran fiber treatments. DeFreitas et al. (1997) demonstrated the influence of added carrageenan on the gelling characteristics of pork salt-soluble meat proteins in model systems. The physical properties of gel systems are also affected, and can be improved, by the concentration of edible seaweeds that is used (Cofrades et al., 2008). The threedimensional gels greatly influence the yield and textural properties of processed meat products. The gelling forms a three-dimensional structure related to a polymerization reaction between the protein molecules. Reduced-fat or low-fat meat products may be partly substituted by water and isolated soy protein, carrageenan, maltodextrins, chitosan, and dietary fiber, which helps improve emulsion stability and textural properties (Chin et al., 1999; Choi et 
al., 2010a; García-García and Totosaus, 2008; Park et al., 2004).

Makgeolli lees fiber has so far been of limited use in the food industry as a fiber source (Choi et al., 2010b). A great deal of Makgeolli lees is produced annually in Korea, and the by-products of Makgeolli brew processing are commonly used as animal feeds or fertilizers (Blandino et al., 2003; Choi et al., 2010b, Lee et al., 1996). Makgeolli lees provide dietary fiber, proteins, minerals, vitamins, alcohol, and organic acids that are recognized and increasingly sought for improved human health (Jeong and Park, 2006). However, dietary fiber sources such as Makgeolli lees are not only desirable for their nutritional properties but also for their functional and technological properties. Also, the influence of Makgeolli lees fiber on the functional properties of chicken salt-soluble meat proteins is not clearly understood. It is not known whether the Makgeolli lees fiber interacts directly or indirectly with the chicken salt-soluble meat proteins during gel network formation (Choi et al., 2011; McCord et al., 1998).

The objective of this study was to investigate the gelling properties of chicken salt-soluble proteins as affected by various levels of Makgeolli lees fiber, and to contribute to the developments of a salt-soluble chicken protein model system.

\section{Materials and Methods}

\section{Preparation and processing of Makgeolli lees fiber extract}

Dietary fiber was extracted using the modified AOAC enzymatic-gravimetric method (AOAC, 1995; Choi et al., 2009). Makgeolli lees was obtained from Seoul Takju Map Association, Seoul, Korea, alcoholic components were removed by triple washing with four volumes of water $\left(25^{\circ} \mathrm{C}\right)$, and the residue was dried $\left(55^{\circ} \mathrm{C}\right)$ overnight in an air oven and then cooled. The Makgeolli lees was gelatinized with $0.6 \%$ termamyl (heat stable alpha-amylase) at $95^{\circ} \mathrm{C}$ for $1 \mathrm{~h}$ to remove starch, followed by filtration. The residue was then washed three times with four volumes of heated water $\left(100^{\circ} \mathrm{C}\right)$ and allowed to equilibrate to room temperature $\left(20^{\circ} \mathrm{C}\right)$ over $6 \mathrm{~h}$. The residue was then washed with $99.9 \%$ ethanol preheated to $60^{\circ} \mathrm{C}$, followed by filtration. The residue was dried $\left(55^{\circ} \mathrm{C}\right)$ overnight in an air oven and then cooled. The Makgeolli lees fiber (moisture content: $3.42 \pm 0.14 \%$; fat content: $5.98 \pm 0.28 \%$; protein content: $15.51 \pm 0.78 \%$; ash content: $0.60 \pm 0.06 \%$; dietary fiber content: $60.39 \pm 3.81 \%$; CIE L ${ }^{*}$-value: 67.35 \pm 1.02 ; CIE a ${ }^{*}$-value: $4.62 \pm 0.45$; CIE $b^{*}$-value: $16.09 \pm 0.85$; $\mathrm{pH}: 4.76 \pm 0.24)$ was then placed in polyethylene bags, vacuum packaged using a model FJ-500XL vacuum packaging system (Fujee Tech, Korea) and stored at $4^{\circ} \mathrm{C}$ until used for product manufacture (Choi et al., 2010b).

\section{Protein extraction}

Fresh chicken breast meat (M. pectoralis major) was purchased from a local processor. Chicken breast meats were initially ground through an 8 -mm plate and then ground through a $3-\mathrm{mm}$ plate. The ground tissue was then placed in polyethylene bags, vacuum packaged using a vacuum packaging system (FJ-500XL, Fujee Tech, Korea) and stored at $0^{\circ} \mathrm{C}$ until required for salt-soluble protein manufacture. The samples were allowed to equilibrate at $2^{\circ} \mathrm{C}$ and the meat $\mathrm{pH}$ was determined with a $\mathrm{pH}$ meter (Model 340, Mettler-Toledo GmbH, Switzerland) after mixing $10 \mathrm{~g}$ of ground muscle with $90 \mathrm{~mL}$ deionized-distilled water for $1 \mathrm{~min}$. One part meat and two parts 0.58 M saline $\left(0.49 \mathrm{M} \mathrm{NaCl}, 17.8 \mathrm{mM} \mathrm{Na}_{5} \mathrm{P}_{3} \mathrm{O}_{10}\right.$ and $1 \mathrm{mM}$ $\mathrm{NaN}_{3}, \mathrm{pH} 8.3,2^{\circ} \mathrm{C}$ ) solution of the same ionic strength and $\mathrm{pH}$ were blended for $30 \mathrm{~s}$ in a blender. The slurry was kept at $2^{\circ} \mathrm{C}$ for $1 \mathrm{~h}$ and then centrifuged $\left(12,000 \mathrm{~g}, 2^{\circ} \mathrm{C}\right)$ for $1 \mathrm{~h}$ in a Supra $25 \mathrm{~K}$ high speed refrigerated centrifuge (Hanil Science Industrial, Korea). The protein extract was strained through three layers of cheesecloth (Camou et al., 1989). Protein concentrations of the meat solids and supernatant were determined using a Kjeltec $\left({ }^{\circledR} 2300\right.$ nitrogen analyzer (Foss Tecator AB, Sweden). Nitrogen was converted to protein by multiplying by 6.25 . Moisture and fat determinations were performed by AOAC (1995) methods.

\section{Gel preparation}

Chicken salt-soluble meat protein solutions were diluted to $5 \%$ protein with a saline solution of the same $\mathrm{pH}(6.0)$ as the protein extract, transferred to glass gelling tubes, and various amounts of Makgeolli lees fiber were added. The sealed tubes were centrifuged at $800 \mathrm{~g}$ for 15 $\min$ at $4^{\circ} \mathrm{C}$ to remove air bubbles. Samples were equilibrated at $20^{\circ} \mathrm{C}$ for $10 \mathrm{~min}$ in a water bath, heated to $90^{\circ} \mathrm{C}$ at $1.75^{\circ} \mathrm{C} / \mathrm{min}$ and held at $90^{\circ} \mathrm{C}$ for $20 \mathrm{~min}$. After heating, the tubes were immersed in water overnight at $4^{\circ} \mathrm{C}$ (McCord et al., 1998).

\section{pH}

The $\mathrm{pH}$ values of sample were determined with a $\mathrm{pH}$ meter (Model 340, Mettler-Toledo GmbH, Switzerland). The $\mathrm{pH}$ of the gel was measured after blending $5 \mathrm{~g}$ of 
sample with $20 \mathrm{~mL}$ of distilled water for $60 \mathrm{~s}$ in homogenizer (Ultra-Turrax SK15, Janke \& Kunkel, Germany). All determinations were performed in triplicate.

\section{Proximate composition}

Compositional properties of the samples were determined using AOAC procedures (1995). Moisture content (950.46B, oven air-drying method) was determined by weight loss after $12 \mathrm{~h}$ of drying at $105^{\circ} \mathrm{C}$ in a SW-90D drying oven (Sang Woo Scientific, Korea). Fat content (960.69, ether extractable component) was determined by the Soxhlet method with a Soxtec $\circledR$ Avanti 2050 auto solvent extraction system (Foss Tecator AB, UK), and protein content (981.10) was determined by the aforementioned Kjeldahl method. Ash content was determined according to AOAC method 920.153 (muffle furnace).

\section{Water holding capacity (WHC)}

WHC was measured gravimetrically (Kocher and Foegeding, 1993) using heat-induced gels prepared from five formulations (0 (control), 0.5, 1.0, 2.0, and 4.0\% Makgeolli lees fiber). Before thermal processing, the sealed tubes were centrifuged at $800 \mathrm{~g}$ expressed using the following formula:

$$
\text { WHC }(\%)=[1-(\mathrm{ML} / \mathrm{CG})] \times 100
$$

where ML is the weight of the moisture loss from the gel after centrifugation and $\mathrm{CG}$ is the weight of the cooked gel.

Data represent the mean values from three replicates. One replicate consisted of three observations per treatment.

\section{Color evaluation}

The color of each gel was determined using a Minolta Chroma meter CR-210 colorimeter (Minolta, Japan; illuminate $\mathrm{C}$, calibrated with a white plate, CIE $\mathrm{L}^{*}=+97.83$, CIE $\mathrm{a}^{*}=-0.43$, and CIE $\mathrm{b}^{*}=+1.98$ ). Six measurements for each of five replicates were taken.

\section{Apparent viscosity}

Each gel viscosity was measured in triplicate with a Hakke Viscotester®500 rotational viscometer (Thermo Electron, Germany) set at $10 \mathrm{rpm}$. The standard cylinder sensor (SV-E) was positioned in a $50 \mathrm{~mL}$ plastic cup filled with gel and allowed to rotate under a constant rate at $\mathrm{s}^{-1}$ for $30 \mathrm{~s}$ before each reading was taken. Apparent viscosity values in centipoises were obtained. The tem- perature $\left(18^{\circ} \mathrm{C}\right)$ of each sample at the time of viscosity testing was also recorded (Park et al., 2004).

\section{Texture profile analysis (TPA)}

The textural properties of chicken salt-soluble meat protein samples during thermal gelation were measured with a TA-XT2 $i$, texture analyzer (Stable Micro Systems, UK) with $25 \mathrm{~kg}$ load cell. The centre core of heat-induced gel samples were cut $(20 \mathrm{~mm}$ in diameter, $15 \mathrm{~mm}$ in height) and compressed twice to $30 \%$ of their original height at a constant cross-head speed of $2.0 \mathrm{~mm} / \mathrm{s}$. The conditions of texture analysis were as follows: pre-test speed $2.0 \mathrm{~mm} / \mathrm{s}$, post-test speed $5.0 \mathrm{~mm} / \mathrm{s}$, maximum load $2 \mathrm{~kg}$, head speed $2.0 \mathrm{~mm} / \mathrm{s}$, distance $8.0 \mathrm{~mm}$, force $10 \mathrm{~g}$. TPA parameters were hardness [peak force on first compression $(\mathrm{kg})$ ], springiness [ratio of the sample recovered after the first compression], cohesiveness [ratio of the active work done under the second force-displacement curve to that done under the first compression curve], gumminess [hardness $\times$ cohesiveness $(\mathrm{kg})]$, and chewiness [hardness $\times$ cohesiveness $\times$ springiness $(\mathrm{kg})]$ (Bourne, 1982).

\section{Protein solubility}

Protein solubility was utilized as an indicator of protein denaturation (Joo et al., 1999). Sarcoplasmic protein solubility was determined by dissolving $2 \mathrm{~g}$ of muscle powder in $20 \mathrm{~mL}$ of ice-cold $25 \mathrm{mM}$ potassium phosphate buffer ( $\mathrm{pH}$ 7.2). The heat-induced gel samples concentrations of the supernatants were determined using the Biuret method (Gornall et al., 1949). Total protein solubility was determined by homogenizing $2 \mathrm{~g}$ of muscle powder in $20 \mathrm{~mL}$ of ice-cold $1.1 \mathrm{~mol} / \mathrm{L}$ potassium iodide in a $100 \mathrm{~mol} / \mathrm{L}$ phn concentrations of the supernatants were determined using the Biuret method (Gornall et al., 1949). Total protein solubility was determined by homogenizing $2 \mathrm{~g}$ of muscle powder in $20 \mathrm{~mL}$ of ice-cold 1.1 $\mathrm{mol} / \mathrm{L}$ potassium iodide in a $100 \mathrm{~mol} / \mathrm{L}$ phosphate buffer ( $\mathrm{pH}$ 7.2). The procedures for homogenization, shaking, centrifugation, and protein determination are described above. Myofibrillar protein solubility was obtained by determining the difference between the total and sarcoplasmic protein solubilities.

\section{Sodium dodecyl sulfate polyacrylamide gel electro- phoresis (SDS-PAGE)}

SDS-PAGE was performed according to the procedure of Laemmli (1970). SDS-PAGE samples were prepared by adjusting the protein concentration to $6.4 \mathrm{mg} / \mathrm{mL}$. Each diluted sample was combined with 0.5 volumes of 
sample buffer/SDS gel loading buffer (50 mM Tris-Cl pH 6.8, $100 \mathrm{mM}$ dithiothreitol, $2 \%(\mathrm{w} / \mathrm{v})$ SDS, $0.1 \%$ bromophenol blue, $10 \%(\mathrm{w} / \mathrm{v})$ glycerol) and loaded into the separate wells of a Mini-Protean 3 cell (Bio-Rad Laboratories, USA). Ten percent polyacrylamide separating gels contained $30 \%$ acrylamide mix (29:1 acrylamide: bisacrylamide), $0.375 \mathrm{M}$ Tris- $\mathrm{HCl}, \mathrm{pH} 8.8,0.1 \%(\mathrm{w} / \mathrm{v})$ sodium dodecyl sulfate (SDS), $0.1 \%(\mathrm{w} / \mathrm{v})$ ammonium persulfate, and $0.04 \%(\mathrm{v} / \mathrm{v}) \mathrm{N}, \mathrm{N}, \mathrm{N}^{\prime}, \mathrm{N}^{\prime}$-tetramethylenediamine (TEMED). The 5\% stacking gel contained 30\% acrylamide mix (29:1 acrylamide:bisacrylamide), $0.1 \mathrm{M}$ Tris-HCl, pH 6.8, 0.1\%(w/v) SDS, 0.1\%(v/v) TEMED, and $0.1 \%$ ammonium persulfate. Gels were run at $100 \mathrm{~V}$ for approximately $40 \mathrm{~min}$ at room temperature, using Tris-glycine electrophoresis buffer ( $25 \mathrm{mM}$ Tris, $250 \mathrm{mM}$ glycine $\mathrm{pH} 8.3,0.1 \%(\mathrm{w} / \mathrm{v})$ SDS as the running buffer. Gels were stained with $0.25 \%(\mathrm{w} / \mathrm{v})$ Coomassie Brilliant Blue R-250, 50\%(v/v) methanol, and 10\%(v/v) acetic acid for $12 \mathrm{~h}$ and de-stained in the same solution without Coomassie Brilliant Blue R-250 (Weber and Osborn, 1969). Molecular weights were determined relative to high and low molecular weight standard mixtures (Sigma-Aldrich, USA).

\section{Statistical analysis}

The experiment was replicated three times, each with a new batch of salt-soluble meat protein and the data were analyzed using the general linear model (GLM) procedure of the SAS statistical package (2008). Main factors included Makgeolli lees fiber level (0, 0.5, 1.0, 2.0, and $4.0 \%)$. When an interaction between factors was found to be significant $(p<0.05)$, means were separated out by treatment groups. If the interaction was not significant, data were pooled to test the main effect using Duncan's multiple range test.

\section{Results and Discussion}

\section{Proximate compositions of chicken salt-soluble protein heat-induced gel systems with Makgeolli lees fiber}

The proximate compositions of the heat-induced gel samples containing Makgeolli lees fiber are shown in Table 1. The moisture contents of heat-induced gels samples containing Makgeolli lees fiber were higher than that of the control samples without Makgeolli lees fiber $(p<0.05)$. Increasing levels of Makgeolli lees fiber significantly increased the moisture content of chicken salt-soluble protein heat-induced gel systems $(p<0.05)$, because higher moisture content gives increased water binding capacity to heat-induced gels. These results agree with those reported by Choi et al. (2011), in which the moisture content significantly increased with the addition of rice bran fiber to pork salt-soluble protein heat-induced gels. Similar results were obtained by Osburn and Keeton (2004) for a konjac gel matrix prepared with low-fat sausage emulsions. Increasing levels of konjac increased the moisture content because the addition of konjac was related with higher water holding capacities of the hydrocolloid gel. The protein and fat contents did not significantly differ between control and treatments with Makgeolli lees fiber $(p>0.05)$. The ash contents of chicken heatinduced gels were higher in formulations containing Makgeolli lees fiber than in the control $(p<0.05)$, consistent with the influence of minerals and vitamins in the Makgeolli lees fiber on the heated-mediated induction of gel formation. Choi et al. (2010a) reported similar results for the addition of rice bran fiber to reduced-fat frankfurters, which likely reflected the minerals in the rice bran fiber. These results agree with the result of Cofrades et al. (2008), who that the ash content significantly increased with the level of edible seaweeds added to gel meat systems. The ash levels of gel meat systems were higher to the edible seaweeds added, because the edible seaweed

Table 1. Proximate composition of chicken salt-soluble protein heat-induced gel systems formulated with Makgeolli lees fiber

\begin{tabular}{lccccc}
\hline \hline Parameters & Control & T1 & T2 & T3 & T4 \\
\hline Moisture (\%) & $83.03 \pm 0.27^{\mathrm{e}}$ & $85.21 \pm 0.15^{\mathrm{d}}$ & $86.17 \pm 0.23^{\mathrm{c}}$ & $87.04 \pm 0.22^{\mathrm{b}}$ & $87.40 \pm 0.35^{\mathrm{a}}$ \\
Protein (\%) & $10.14 \pm 0.35$ & $10.12 \pm 0.34$ & $9.97 \pm 0.24$ & $9.82 \pm 0.28$ & $9.74 \pm 0.31$ \\
Fat (\%) & $0.62 \pm 0.21$ & $0.74 \pm 0.28$ & $0.75 \pm 0.17$ & $0.78 \pm 0.34$ & $0.89 \pm 0.32$ \\
Ash (\%) & $2.78 \pm 0.08^{\mathrm{c}}$ & $2.82 \pm 0.04^{\mathrm{b}}$ & $2.82 \pm 0.08^{\mathrm{b}}$ & $2.83 \pm 0.04^{\mathrm{ab}}$ & $2.86 \pm 0.07^{\mathrm{a}}$ \\
\hline
\end{tabular}

All values are the mean \pm SD of three replicates.

${ }^{\mathrm{a}-\mathrm{e}}$ Means within a row with different letters are significantly different $(p<0.05)$.

Control, no addition of Makgeolli lees fiber; T1, 0.5\% Makgeolli lees fiber; T2, 1.0\% Makgeolli lees fiber; T3, 2.0\% Makgeolli lees fiber; T4, 4.0\% Makgeolli lees fiber. 
treatment sample has containing dietary fiber and mineral.

\section{pH and color of chicken salt-soluble protein heat- induced gel systems with Makgeolli lees fiber}

Table 2 provides data concerning $\mathrm{pH}$, lightness (CIE $\mathrm{L}^{*}$-value), redness (CIE a*-value), and yellowness (CIE $\mathrm{b}^{*}$-value) values for chicken salt-soluble protein heatinduced gels formulated with Makgeolli lees fiber levels. Uncooked and cooked control had the highest $\mathrm{pH}$ values $(p<0.05)$. Increasing levels of Makgeolli lees fiber were related with lower $\mathrm{pH}$ of the chicken salt-soluble protein heat-induced gels $(p<0.05)$, probably due to effect of the Makgeolli lees fiber $(\mathrm{pH}, 4.76)$. These results agree with those reported by Choi et al. (2010b), in which the $\mathrm{pH}$ significantly decreased with the addition of Makgeolli lees fiber to meat emulsion model systems. For this reason, Makgeolli lees fiber contained organic acids and lactic acid bacteria. Similarly, Jeong and Park (2006) reported that added Makgeolli powder decreased the $\mathrm{pH}$ values of food due to the influence of organic acids, saccharides, and lactic acid bacteria contained in the added Makgeolli.

The differences in lightness, redness, and yellowness values of chicken salt-soluble protein heat-induced gels containing Makgeolli lees fiber were significantly difference $(p<0.05)$ (Table 3$)$. The lightness of uncooked and cooked controls were higher than the treatments with Makgeolli lees fiber, as increasing levels of Makgeolli lees fiber decreased lightness $(p<0.05)$. The redness and yellowness values of uncooked and cooked gels was significantly increased with increasing Makgeolli lees fiber levels $(p<0.05)$, because the gel affected by the Makgeolli lees fiber color (CIE L*-value: 67.35 \pm 1.02 ; CIE a ${ }^{*}$-value: $4.62 \pm 0.45$; CIE $b^{*}$-value: $16.09 \pm 0.85$ ). Similar results were obtained by Choi et al. (2011) for heat-induced gel prepared with pork salt-soluble meat protein in model systems with added rice bran fiber. These results obtained the lightness and redness values of gels decreased and the yellowness values of gels increased with increasing levels of rice bran fiber. Choi et al. (2010b) observed that color evaluations of meat emulsion systems with added Makgeolli lees fiber show decreased lightness and redness values, and increased yellowness values. The color values of meat products are influenced to the addition of colored dietary fiber from natural sources (Choi et al., 2008, 2011; Cofrades et al., 2008; Eim et al., 2008; Lee et al., 2008).

Table 2. pH and color parameters of chicken salt-soluble protein heat-induced gels formulated with Makgeolli lees fiber

\begin{tabular}{|c|c|c|c|c|c|c|}
\hline & Parameters & Control & $\mathrm{T} 1$ & $\mathrm{~T} 2$ & $\mathrm{~T} 3$ & $\mathrm{~T} 4$ \\
\hline \multirow{4}{*}{ Uncooked } & $\mathrm{pH}$ & $6.70 \pm 0.02^{\mathrm{a}}$ & $6.67 \pm 0.02^{\mathrm{ab}}$ & $6.66 \pm 0.03^{\mathrm{b}}$ & $6.63 \pm 0.02^{\mathrm{c}}$ & $6.58 \pm 0.03^{\mathrm{d}}$ \\
\hline & CIE L ${ }^{*}$-value & $62.30 \pm 0.32^{\mathrm{a}}$ & $58.52 \pm 0.56^{\mathrm{b}}$ & $57.56 \pm 0.95^{\mathrm{b}}$ & $57.39 \pm 0.42^{\mathrm{b}}$ & $56.66 \pm 0.78^{c}$ \\
\hline & CIE a -value & $-0.85 \pm 0.32^{\mathrm{e}}$ & $-0.49 \pm 0.18^{\mathrm{d}}$ & $0.16 \pm 0.44^{\mathrm{c}}$ & $1.44 \pm 0.48^{\mathrm{b}}$ & $3.82 \pm 0.79^{\mathrm{a}}$ \\
\hline & $\mathrm{CIE}^{*}{ }^{*}$-value & $5.60 \pm 1.16^{\mathrm{d}}$ & $5.87 \pm 0.72^{\mathrm{d}}$ & $9.03 \pm 0.77^{\mathrm{c}}$ & $12.92 \pm 0.85^{\mathrm{b}}$ & $19.07 \pm 0.87^{\mathrm{a}}$ \\
\hline \multirow{4}{*}{ Cooked } & $\mathrm{pH}$ & $6.73 \pm 0.02^{\mathrm{a}}$ & $6.70 \pm 0.02^{\mathrm{b}}$ & $6.68 \pm 0.03^{\mathrm{c}}$ & $6.66 \pm 0.02^{\text {cd }}$ & $6.62 \pm 0.03^{\mathrm{d}}$ \\
\hline & CIE L ${ }^{*}$-value & $82.97 \pm 1.11^{\mathrm{a}}$ & $80.86 \pm 0.87^{b}$ & $78.47 \pm 1.33^{\mathrm{c}}$ & $75.22 \pm 1.17^{\mathrm{d}}$ & $71.14 \pm 0.97^{\mathrm{e}}$ \\
\hline & CIE a -value & $-0.63 \pm 0.09^{\mathrm{e}}$ & $-0.05 \pm 0.19^{\mathrm{d}}$ & $0.31 \pm 0.22^{\mathrm{c}}$ & $0.68 \pm 0.19^{\mathrm{b}}$ & $1.26 \pm 0.58^{\mathrm{a}}$ \\
\hline & CIE $b^{*}$-value & $5.22 \pm 0.60^{\mathrm{d}}$ & $6.15 \pm 0.60^{\mathrm{c}}$ & $6.90 \pm 0.48^{\mathrm{c}}$ & $9.19 \pm 0.55^{\mathrm{b}}$ & $11.48 \pm 0.87^{\mathrm{a}}$ \\
\hline
\end{tabular}

All values are the mean $\pm \mathrm{SD}$ of three replicates.

${ }^{a-e}$ Means within a row with different letters are significantly different $(p<0.05)$.

Control, no addition of Makgeolli lees fiber; T1, 0.5\% Makgeolli lees fiber; T2, 1.0\% Makgeolli lees fiber; T3, 2.0\% Makgeolli lees fiber; T4, 4.0\% Makgeolli lees fiber.

Table 3. Texture profile analysis of chicken salt-soluble protein heat-induced gels formulated with Makgeolli lees fiber

\begin{tabular}{lccccc}
\hline \hline Parameters & Control & T1 & T2 & T3 & T4 \\
\hline Hardness (kg) & $0.55 \pm 0.08^{\mathrm{e}}$ & $0.60 \pm 0.08^{\mathrm{bc}}$ & $0.63 \pm 0.07^{\mathrm{b}}$ & $0.66 \pm 0.06^{\mathrm{b}}$ & $0.90 \pm 0.10^{\mathrm{a}}$ \\
Springiness & $0.86 \pm 0.03^{\mathrm{d}}$ & $0.98 \pm 0.01^{\mathrm{a}}$ & $0.96 \pm 0.02^{\mathrm{ab}}$ & $0.94 \pm 0.03^{\mathrm{b}}$ & $0.92 \pm 0.02^{\mathrm{c}}$ \\
Cohesiveness & $0.35 \pm 0.04^{\mathrm{c}}$ & $0.43 \pm 0.04^{\mathrm{b}}$ & $0.47 \pm 0.05^{\mathrm{b}}$ & $0.51 \pm 0.05^{\mathrm{a}}$ & $0.52 \pm 0.04^{\mathrm{a}}$ \\
Gumminess (kg) & $0.19 \pm 0.04^{\mathrm{d}}$ & $0.26 \pm 0.04^{\mathrm{c}}$ & $0.30 \pm 0.06^{\mathrm{bc}}$ & $0.34 \pm 0.05^{\mathrm{b}}$ & $0.45 \pm 0.05^{\mathrm{a}}$ \\
Chewiness (kg) & $0.17 \pm 0.05^{\mathrm{d}}$ & $0.28 \pm 0.04^{\mathrm{c}}$ & $0.33 \pm 0.05^{\mathrm{b}}$ & $0.35 \pm 0.06^{\mathrm{b}}$ & $0.44 \pm 0.04^{\mathrm{a}}$
\end{tabular}

All values are the mean $\pm \mathrm{SD}$ of three replicates.

${ }^{\mathrm{a}-\mathrm{e}}$ Means within a row with different letters are significantly different $(p<0.05)$.

Control, no addition of Makgeolli lees fiber; T1, 0.5\% Makgeolli lees fiber; T2, 1.0\% Makgeolli lees fiber; T3, 2.0\% Makgeolli lees fiber; T4, 4.0\% Makgeolli lees fiber. 


\section{Water holding capacity of chicken salt-soluble pro- tein heat-induced gel systems with Makgeolli lees fiber}

The water holding capacity of chicken salt-soluble protein heat-induced gel systems are depicted in Fig. 1. The water holding capacity of pure chicken salt-soluble protein in the control was $80.45 \%$, whereas the heat-induced gels with added Makgeolli lees fiber had greater water holding capacities than the control $(p<0.05)$. These results are in agreement with a study that reported that heatinduced gel prepared with pork salt-soluble proteins in model systems are affected by rice bran fiber (Choi et al., 2011). The pork salt-soluble proteins in model systems with added rice bran fiber had greater water holding capacity than the control. Furthermore, McCord et al. (1998) reported that heat-induced gelation characteristics of salt-soluble proteins are influenced by whey protein isolate. DeFreitas et al. (1997) observed that the salt-soluble meat protein gels with added carrageenan increased water retention, because higher water holding capacity gives improving binding capacity between the meat protein and water to salt-soluble meat protein gels. The water holding capacity of a hydrocolloid gel can be attributed to increasing moisture content with increasing levels of konjac (Osburn and Keeton, 2004). In general, the increased water holding capacity can be largely attributed to the total amount of solubilized myosin, since myosin is largely responsible (Choi et al., 2011; Nakayama and Sato, 1971), and heat-induced gel requires the association of myosin and actin chains, which produces a continuous three-dimensional network in which water is captured

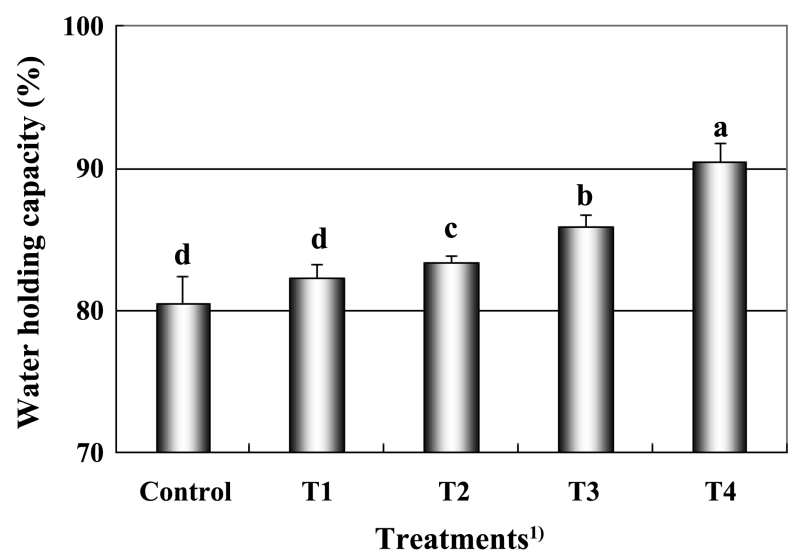

Fig. 1. Water holding capacity of chicken salt-soluble protein heat-induced gels formulated with Makgeolli lees fiber. ${ }^{\mathrm{a}-\mathrm{d}}$ Means in the treatments with different letters are significantly different $(p<0.05)$. Control, no addition of Makgeolli lees fiber; T1, 0.5\% Makgeolli lees fiber; T2, 1.0\% Makgeolli lees fiber; T3, 2.0\% Makgeolli lees fiber; T4, 4.0\% Makgeolli lees fiber.
(Liu et al., 2008).

Protein solubility of chicken salt-soluble protein heat-induced gel systems with Makgeolli lees fiber

The protein solubility of sarcoplasmic, myofibrillar, and total proteins in the chicken salt-soluble protein heatinduced gel systems formulated with different levels of Makgeolli lees fiber are presented in Fig. 2. The sarcoplasmic, myofibrillar, and total protein solubilities in the chicken salt-soluble protein heat-induced gel systems were not significantly different between the control and the Makgeolli lees fiber treatments samples ( $p>0.05)$, due to same salt and phosphate concentration in the samples treatments added. It is for this reason that protein solubility of meat products is influenced by water holding capacity of meat, but salt or phosphate concentrations in the sample are the major factor to affect the protein solubility in meat products. Dietary fiber from Makgeolli lees is useful due to its ability to enhance water holding capacity in meat products, but protein solubilities did not affected. Farouk et al. (2002) reported that protein solubility during cooking can influence textural and rheological properties. The protein solubility of salted cooked batters is higher in salt-soluble protein solubility than unsalted meat batters (Farouk and Swan, 1997). Sayre and Briskey (1963) reported that protein solubility in meat of important different qualities characteristics is influenced by careful control of the conditions, and that protein solubility appears to provide a better indication of meat product quality. Thus, gels formation in chicken salt-soluble protein heat-induced gel systems can be affected by the concentration and contents of myofibrillar protein, the

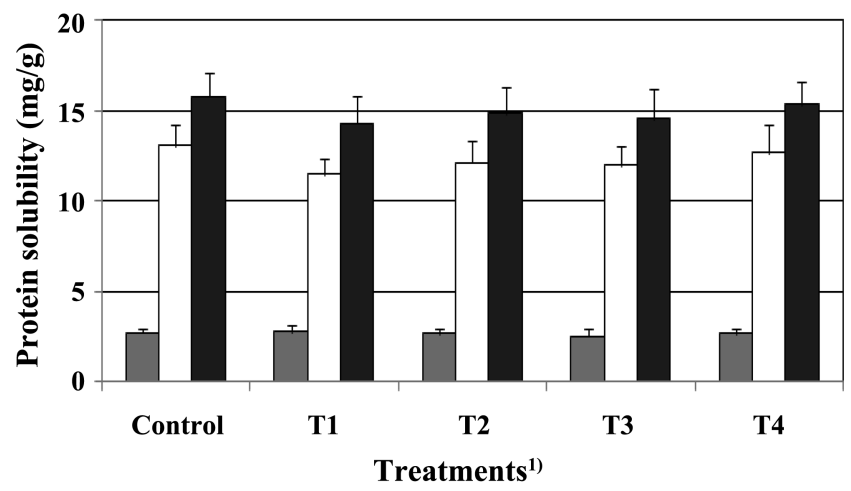

Fig. 2. Protein solubility of chicken salt-soluble protein heatinduced gels formulated with Makgeolli lees fiber. ${ }^{\mathrm{a}-\mathrm{d}}$ Means in the treatments with different letters are significantly different $(p<0.05)$. Control, no addition of Makgeolli lees fiber; T1, 0.5\% Makgeolli lees fiber; T2, 1.0\% Makgeolli lees fiber; T3, 2.0\% Makgeolli lees fiber; T4, 4.0\% Makgeolli lees fiber. 
type and concentration of salts and phosphates, water holding capacity, $\mathrm{pH}$, processing time, and temperature, and additives that form self-complexes or complexes with other components (Choi et al., 2011; Lanier, 1991).

\section{Apparent viscosity of chicken salt-soluble protein} heat-induced gel systems with Makgeolli lees fiber

The Makgeolli lees fiber concentration significantly affected the apparent viscosity of chicken salt-soluble protein unheated gels (Fig. 3). In general, apparent viscosity is related to the textural properties and water holding capacity in model systems. The control and all the treatments with added Makgeolli lees fiber samples displayed thixotropic behavior with apparent viscosity values that decreased with increasing rotation time. Similar results were found by Choi et al. (2011) who observed that addition of rice bran fiber to pork salt-soluble protein gels results in decreased viscosity with increasing rotation time. The control gel samples had the lowest maximum viscosity, while samples with increasing Makgeolli lees fiber concentration had progressively higher maximum viscosity values due to the fiber to high binding capacity between salt-soluble protein and water. The significant changes in apparent viscosity observed for unheated chicken salt-soluble protein gels were due to higher dietary fiber. These results agree with the observation of Choi et al. (2010b) that the addition of Makgeolli lees fiber to emulsion systems samples resulted in significantly increased apparent viscosity as the content of Makgeolli lees fiber increased, as higher viscosity imparted increased elasticity to the emulsion systems. Moreover, Park et al. (2004)

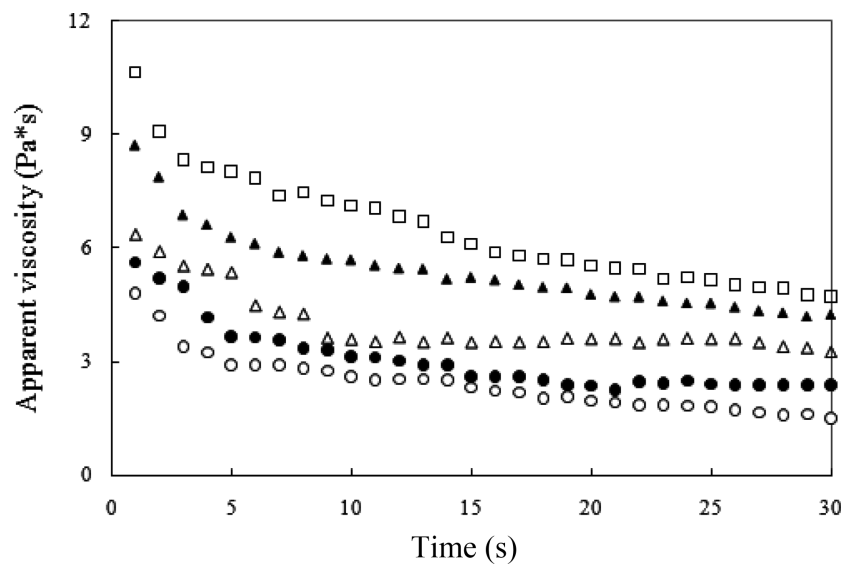

Fig. 3. Apparent viscosity of chicken salt-soluble protein heat-induced gels formulated with Makgeolli lees fiber. $(\bigcirc)$ Control, no addition of rice bran fiber; $(0) \mathrm{T} 1$, $0.5 \%$ Makgeolli lees fiber; $(\triangle)$ T2, 1.0\% Makgeolli lees fiber; ( $\Delta$ ) T3, 2.0\% Makgeolli lees fiber; $(\square)$ T4, 4.0\% Makgeolli lees fiber observed that heat-induced gel prepared from pork saltsoluble protein with added combined water soluble chitooligosaccharide and chitosan samples significantly increases viscosity with increased addition. Increasing viscosity is related with improved emulsion stability, and high viscosity are not easily broken emulsion in model systems (Aktas and Genccelep, 2006; Choi et al., 2011).

\section{TPA of chicken salt-soluble protein heat-induced gel systems with Makgeolli lees fiber}

The textural properties of chicken salt-soluble protein heat-induced gel systems with different added Makgeolli lees fiber concentration are given in Table 3. The hardness, cohesiveness, gumminess, and chewiness values of heat-induced gels were significantly higher in gels with added Makgeolli lees fiber than the control, as increasing Makgeolli lees fiber levels increased hardness, cohesiveness, gumminess, and chewiness, perhaps due to the ability of Makgeolli lees fiber to create a stronger binding three-dimensional network. These results are agree with reported that meat emulsion systems with rice bran fiber display increased emulsion system hardness, cohesiveness, gumminess, and chewiness values (Choi et al., 2009). Chin (2000) reported that heat-induced gels prepared with salt soluble protein with added konjac flour and carrageenan treatments displayed higher gel hardness than salt soluble protein gel without the added ingredients. Improvement of the textural properties of the heated-induced gel with the addition of konjac flour and carrageenan was primarily due to the physical entrapment of protein and water by the ingredients, resulting in higher gel hardness. According to Westphalen et al. (2006), the hardness of heat-induced gels concerns relationships between viscoelastic properties and the water holding capacity of myofibrillar protein gels. The springiness of heat-induced gels amended with Makgeolli lees fiber was lower than control; the highest springiness in heat-induced gels was obtained with $0.5 \%$ Makgeolli lees fiber (T1). In this study, all parameters of textural profile analysis for chicken salt-soluble protein heat-induced gel systems had higher values with added Makgeolli lees fiber relative to the control without Makgeolli lees fiber. Similar results were obtained by Cofrades et al. (2008) regarding the effect of added edible seaweed on the characteristics of gel/emulsion meat systems, and by Chin (2000) concerning the influence of added konjac and carrageenan on heatinduced gels prepared with pork salt soluble protein. For these reason, the texture of cooked meat products is affected by the gelling capacity of myofibrillar proteins 
and water retention. Nuckles et al. (1991) indicated that protein gelation is one of the major functional properties in emulsified meat products, as it provides desirable textural properties.

\section{Electrophoretic banding pattern of protein extracts of chicken salt-soluble protein heat-induced gel systems with Makgeolli lees fiber}

The electrophoretic pattern of the total soluble proteins is shown in Fig. 4 for chicken salt-soluble protein heatinduced gels with added Makgeolli lees fiber. There was no apparent change in salt-soluble protein heat-induced gels lacking Makgeolli lees fiber. The main alterations of heat-induced gels were the absence of protein bands at 69 $\mathrm{kDa}$ (band A, likely albumin), $37 \mathrm{kDa}$ (band B, likely tropomyosin $\mathrm{bbb}$ ), and $33 \mathrm{kDa}$ (band $\mathrm{C}$, likely tropomysin ß) (Choi et al., 2011; DeFreitas et al., 1997). The chicken salt-soluble protein heat-induced gel proteins contained low intensity bands at approximately $205 \mathrm{kDa}$ (likely myosin heavy chain) and $45 \mathrm{kDa}$ (likely actin). Thus, the electrophoretic banding pattern of protein extracts of chicken salt-soluble protein heat-induced gel systems was not influenced by the addition of Makgeolli lees fiber. In general, myosin heavy chain is the major protein removed by expelled water following during heating (DeFreitas et al., 1997), and light chains dissociate and solubilize when myosin heavy chains aggregate and gel during heating (Samejima et al., 1984). Similar results were obtained by Choi et al. (2011), who reported that actin and myosin heavy chain band from gels mostly disappeared during the high temperature heating. Hofmann (1977) indicated that the presence of sodium chloride has a distinct nega-

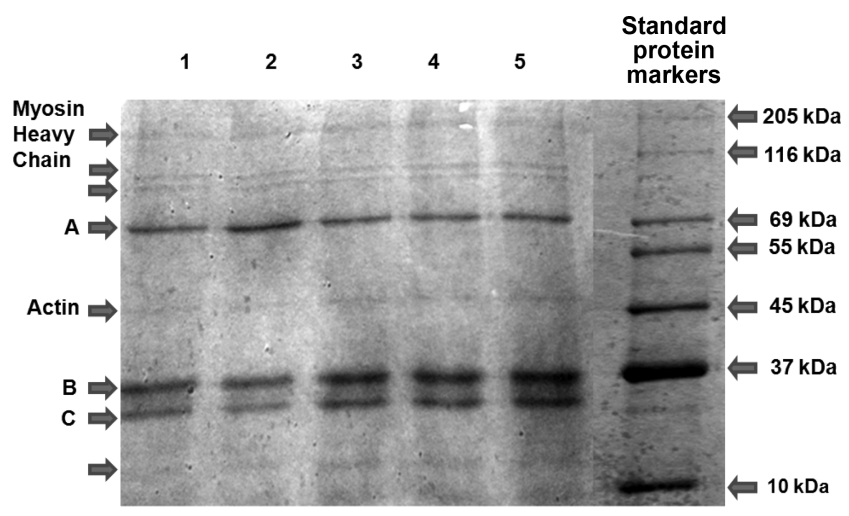

Fig. 4. SDS-PAGE patterns of salt-soluble protein heatinduced gels formulated with Makgeolli lees fiber. Lane 1, control (no addition of Makgeolli lees fiber); Lane 2, T1 (0.5\% Makgeolli lees fiber); Lane 3, T2 (1.0\% Makgeolli lees fiber); Lane 4, T3 (2.0\% Makgeolli lees fiber); Lane 5, T4 (4.0\% Makgeolli lees fiber) tive effect on the intensity of the stained myosin band, while actin exhibits less sensitive behavior.

The technological and functional effects of Makgeolli lees fiber on chicken salt-soluble meat proteins in a model system were investigated. The increased water holding capacity of chicken salt-soluble protein heat-induced gels upon the addition of Makgeolli lees fiber were probably due to the molecular interactions of hydrocolloids among proteins, water, and Makgeolli lees fiber. This study demonstrates that protein mixtures such as sarcoplasmic and myofibrillar protein can be controlled in terms of hardness characteristics by adding Makgeolli lees fiber during gel formation. These results indicate that the functional properties of Makgeolli lees fiber under various conditions in low-fat and reduced-fat meat products involve meat proteins due to the Makgeolli lees fiber alone, with no obvious molecular interactions.

\section{Acknowledgement}

This paper was supported by Konkuk University in 2011.

\section{References}

1. Aktas, N. and Genccelep, H. (2006) Effect of starch type and its modifications on physicochemical properties of bolognatype sausage produced with sheep tail fat. Meat Sci. 74, 404408.

2. AOAC (1995) Official methods of analysis, 16th ed., Association of Official Analytical Chemists, Washington, DC.

3. Bae, S. H., Jung, E. Y., Kim, S. Y., Shin, K. S., and Suh, H. J. (2010) Antioxidant and immune-modulating activities of Korean traditional rice wine, takju. J. Food Biochem. 34, 233-248.

4. Blandino, A., Al-Aseeri, M. E., Pandiella, S. S., Cantero, D., and Webb, C. (2003) Cereal-based fermented foods and beverages. Food Res. Int. 36, 527-543.

5. Bourne, M. C. (1982) Food texture and viscosity: concept and measurement. Academic Press, NY, pp. 118-167.

6. Camou, J. P., Sebranek, J. G., and Olson, D. G. (1989) Effect of heating rate and protein concentration on gel strength and water loss of muscle protein gels. J. Food Sci. 54, 850-854.

7. Chin, K. B. (2000) Functional properties of heat-induced gels prepared with salt soluble proteins, non-meat proteins and hydrocolloids in a model system. Food Sci. Biotechnol. 9, 368-371.

8. Chin, K. B., Keeton, J. T., Longnecker, M. T., and Lamkey, J. W. (1999) Utilization of soy protein isolate and konjac blends in a low-fat bologna (model system). Meat Sci. 53, 45-57.

9. Choi, Y. S., Choi, J. H., Han, D. J., Kim, H. Y., Lee, M. A., 
Kim, H. W., Lee, J. W., Chung, H. J., and Kim, C. J. (2010a) Optimization of replacing pork back fat with grape seed oil and rice bran fiber for reduced-fat meat emulsion systems. Meat Sci. 84, 212-218.

10. Choi, Y. S., Choi, J. H., Han, D. J., Kim, H. Y., Lee, M. A., Kim, H. W., Jeong, J. Y., and Kim, C. J. (2011) Effects of rice bran fiber on heat-induced gel prepared with pork salt-soluble meat proteins in model system. Meat Sci. 88, 59-66.

11. Choi, Y. S., Choi, J. H., Han, D. J., Kim, H. Y., Lee, M. A., Kim, H. W., and Kim, C. J. (2009) Characteristics of low-fat meat emulsion systems with pork fat replaced by vegetable oils and rice bran fiber. Meat Sci. 82, 266-271.

12. Choi, Y. S., Choi, J. H., Han, D. J., Kim, H. Y., Lee, M. A., Lee, E. S., Jeong, J. Y., Paik, H. D., and Kim, C. J. (2008) Effect of rice bran fiber on quality of low-fat tteokgalbi. Food Sci. Biotechnol. 17, 959-964.

13. Choi, Y. S., Park, K. S., Choi, J. H., Kim, H. W., Song, D. H., Kim, J. M., Chung, H. J., and Kim, C. J. (2010b) Physicochemical properties of chicken meat emulsion systems with dietary fiber extracted from Makgeolli lees. Korean J. Food Sci. Ani. Resour. 30, 910-917.

14. Cofrades, S., Lopez-Lopez, I., Solas, M. T., Bravo, L., and Jimenez-Colmenero, F. (2008) Influence of different types and proportions of added edible seaweeds on characteristics of low-salt gel/emulsion meat systems. Meat Sci. 79, 767776.

15. DeFreitas, Z., Sebranek, J. G., Olson, D. G., and Carr, J. M. (1997) Carrageenan effects on salt-soluble meat proteins in model systems. J. Food Sci. 62, 539-543.

16. Farouk, M. M. and Swan, J. E. (1997) Effect of pH at time of salting on the functional properties of pre-rigor beef. Meat Sci. 45, 463-472.

17. Farouk, M. M., Wieliczko, K., Lim, R., Turnwald, S., and MacDonald, G. A. (2002) Cooked sausage batter cohesiveness as affected by sarcoplasmic proteins. Meat Sci. 61, 8590.

18. García-García, E. and Totosaus, A. (2008) Low-fat sodiumreduced sausages: Effect of the interaction between locust bean gum, potato starch and $\beta$-carrageenan by a mixture design approach. Meat Sci. 78, 406-413.

19. Gornall, A. G., Bardawill, C. J., and David, M. M. (1949) Determination of serum proteins by means of the biuret reaction. J. Biol. Chem. 177, 751-766.

20. Jeong, J. W. and Park, K. J. (2006) Quality characteristics of loaf bread added takju powder. Korean J. Food Sci. Technol. 38, $52-58$.

21. Joo, S. T., Kauffman, R. G., Kim, B. C., and Park, G. B. (1999) The relationship of sarcoplasmic and myofibrillar protein solubility to colour and water-holding capacity in porcine longissimus muscle. Meat Sci. 52, 291-297.

22. Kocher, P. and Foegeding, E. (1993) Microcentrifuge-based method for measuring water-holding of protein gels. J. Food Sci. 58, 1040-1046.

23. Koohmaraie, M., Kennick, W. H., Elgasim, E. A., and Anglemier, A. F. (1984) Effects of postmortem storage on muscle protein degradation: Analysis by SDS-polyacrylamide gel electrophoresis. J. Food Sci. 49, 292-294.

24. Laemmli, U. K. (1970) Cleavage of structural proteins during the assembly of the head of bacteriophage T4. Nature 227, 680-685.

25. Lan, Y. H., Novakofski, J., Carr, T. R., and McKeith, F. K. (1993) Assay and storage conditions affect yield of salt-soluble protein from muscle. J. Food Sci. 58, 963-967.

26. Lanier, T. C. (1991) Interactions of muscle and nonmuscle proteins affecting heat-set gel rheology. In: Marcromolecular Interactions and Food Colloid Stability. Parris, N. and Barford, R. A. (eds) American Chemical Society, Symposium Series, Washington, DC, pp. 268-284.

27. Lanier, T. C., Carvajal, P., and Yongaswatdigul, J. (2004) Surimi gelation chemistry. In: Surimi and surini seafood. 2nd ed, Prak, J. W. (ed) Marcel Dekker, Inc., NY, pp. 451-470.

28. Lee, J. S., Lee, T. S., Noh, B. S., and Park, S. O. (1996) Quality characteristics of mash of takju prepared by different raw materials. Korean J. Food Sci. Technol. 28, 330-336.

29. Lee, M. A., Han, D. J., Jeong, J. Y., Choi, J. H., Choi, Y. S., Kim, H. Y., Paik, H. D., and Kim, C. J. (2008) Effect of kimchi powder level and drying methods on quality characteristics of breakfast sausage. Meat Sci. 80, 708-714.

30. Liu, R., Zhao, S, M., Xiong, S. B., Xie, B. J., and Qin, L. H. (2008) Role of secondary structures in the gelation of porcine myosin at different $\mathrm{pH}$ values. Meat Sci. 80, 632-639.

31. McCord, A., Smyth, A., and O'Neill, E. E. (1998) Heatinduced gelation properties of salt-soluble muscle proteins as affected by non-meat proteins. J. Food Sci. 63, 580-583.

32. Nakayama, T. and Sato, Y. (1971) Relationship between binding quality of meat and myofibrillar protein. J. Texture Stud. 2, 475-488.

33. Nuckles, R. O., Smith, D. M., and Merkel, R. A. (1991) Properties of heat-induced gels from beef skeletal, heart, lung and spleen protein fractions. J. Food Sci. 56, 1165-1170.

34. Osburn, W. N. and Keeton, J. T. (2004) Evaluation of low-fat sausage containing desinewed lamb and konjac gel. Meat Sci. 68, 221-233.

35. Park, S. Y., Wang, S. H., Chin, K. B., and Kim, Y. D. (2004) Rheological properties of the mixture and heat-induced gel prepared from pork salt soluble protein in combined with soluble chitooligosaccharide and chitosan. Korean J. Food Sci. Technol. 36, 594-597.

36. Samejima, K., Yamaguchi, H., Asghar, A., and Yasui, T. (1984) Role of myosin heavy chains from rabbit skeletal muscle in the heat-induced gelation mechanism. Agric. Biol. Chem. 48, 2225-2232.

37. SAS (2008) SAS/STAT Software for PC. Release 9.2, SAS Institute Inc., Cary, NC, USA.

38. Sayre, R. N. and Briskey, E. J. (1963) Protein solubility as influenced by physiological conditions in the muscle. $J$. Food Sci. 28, 675-679.

39. Smith, D. M. (1998) Meat proteins: Functional properties of comminuted meat products. Food Technol. 42, 116-121.

40. Verbeken, D., Neirinck, N., Van-Der, M. P., and Dewettinck, K. (2005) Influence of $\beta$-carrageenan on the thermal gelation of salt-soluble meat proteins. Meat Sci. 70, 161-166. 
41. Wang, S. F., Smith, D. M., and Steffe, J. F. (1990) Effect of $\mathrm{pH}$ on the dynamic rhelogical properties of chicken breast salt-soluble protein during heat-induced gelation. Poultry Sci. 69, 2220-2227.

42. Weber, K. and Osborn, M. (1969) The reliability of molecular weight determinations by dodecyl sulfate-polyacrylamide gel electrophoresis. J. Biol. Chem. 244, 4406-4412.

43. Westphalen, A. D., Briggs, J. L., and Lonergan, S. M. (2006)
Influence of muscle type on rheological properties of porcine myofibrillar protein during heat-induced gelation. Meat Sci. 72, 697-703.

44. Xiong, Y. L. (1997) Structure-function relationships of muscle proteins. In: Food proteins and their applications. Damondaran, S. and Paraf, A. (eds) Marcel Dekker, Inc., NY, pp. 341-392.

$\overline{\text { (Received 2011.9.17/Revised 2011.10.15/Accepted 2011.10.19) }}$ 